PRZEGLĄD BIBLIOTECZNY 2018 z. 2

PL ISSN 0033-202X

\author{
MAŁGORZATA GÓRALSKA \\ Instytut Informacji Naukowej i Bibliotekoznawstwa \\ Uniwersytet Wrocławski \\ e-mail: malgorzata.goralska@uwr.edu.pl
}

\title{
ZWROT AFEKTYWNY A WSPÓŁCZESNE BADANIA NAD KSIĄŻKĄ I CZYTELNIKIEM. REKONESANS BADAWCZY
}

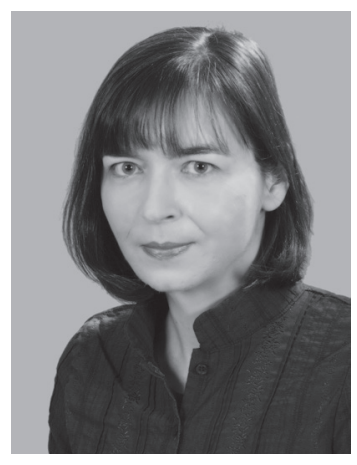

Małgorzata Góralska, dr hab. jest kierownikiem Zakładu Książki Współczesnej i Edytorstwa w Instytucie Informacji Naukowej i Bibliotekoznawstwa Uniwersytetu Wrocławskiego. Główny obszar jej zainteresowań badawczych skoncentrowany jest wokół zagadnień rewolucji cyfrowej oraz współczesnego oblicza kultury książki. Opublikowała m.in. Piśmienność i rewolucja cyfrowa (Wrocław, 2012), Ksiażki, nowe media $i$ ich czasoprzestrzenie (Warszawa, 2009), a także liczne artykuły i hasła w Encyklopedii ksiażki (Wrocław, 2017).

SŁOWA KLUCZOWE: Zwrot afektywny. Bibliologia. Czytelnik. Emocje książkowe.

ABSTRAKT: Teza/cel artykułu - Zwrot afektywny jest jednym z intensywniej rozwijających się nurtów badawczych w humanistyce współczesnej. Znaczenie czynników emotywnych w procesach komunikacyjnych dostrzegalne jest również w odniesieniu do zachowań i wypowiedzi stanowiących podstawę wymiany informacji w mediach masowych. Celem artykułu jest przedstawienie potencjalnych możliwości rozwinięcia badań nad afektami, emocjami i uczuciami charakterystycznymi dla kultury książki, w tym także wykazanie przydatności zasobów sieciowych w ich poznaniu. Metoda badań - Wykorzystano jakościową analizę danych wtórnych (ang. desk research), stanowiących posty użytkowników forum Książki na witrynie Gazeta.pl. Ze względu na ograniczony charakter badania pod uwagę brane były jedynie wypowiedzi zawierające słowa, których desygnaty mieszczą 
się w kategorii emocji podstawowych (strach, złość, smutek i radość). Wyniki i wnioski - W efekcie osiagnięto złożony i wielowymiarowy obraz emocji książkowych, a także uzyskano potwierdzenie przydatności źródeł internetowych w ich dalszym badaniu.

Podstawowym przedmiotem badań w bibliologii jest książka, chociaż we współczesnym ujęciu tej dyscypliny równie istotnym obszarem pozostaje środowisko, w jakim zachodzą procesy związane $\mathrm{z}$ wytwarzaniem, dystrybucją, użytkowaniem i oddziaływaniem dokumentów piśmienniczych. W kręgu zainteresowań bibliologów znajduje się zatem historyczne ukształtowanie odmiennych form i typów książki, ale także jej wpływ na rozwój cywilizacyjny. Książka występuje z jednej strony, jako użyteczny przedmiot codziennego użytku, który charakteryzuje się swoistą morfologia, z drugiej strony, jest archetypicznym obiektem kulturowym i nośnikiem wielopłaszczyznowego systemu znaczeń. Badane są struktury organizacyjne zajmujące się piśmiennictwem i jego zbiorami, a także poszczególni „ludzie książki”, którzy swoje życie zawodowe i/lub prywatne poświęcili jej sprawom. Ważnym aspektem badań bibliologicznych są również odbiorcy przekazu książkowego, postrzegani zarówno w ujęciu indywidualnym, jak i grupowym, a także masowym. Analizowane są miejsce i ranga książki we współczesnym świecie, prognozowane są jej przyszłe losy. Szczególnie w tym ostatnim aspekcie książka traktowana jest jako jedno z narzędzi komunikacji społecznej i często bywa porównywana z innymi mediami. Obok działań zmierzających do poszerzenia wiedzy o konwencjonalnych drukach, składających się na wielowiekowy fenomen książki, pojawiają się nowe wyzwania o charakterze bibliologicznym. Jednym z nich jest niewątpliwie sposób istnienia książki w środowisku cyfrowym i konsekwencje ekspansji technologii teleinformatycznych dla tradycyjnej kultury pisma.

Przemiany zachodzące współcześnie w wymiarach technologicznych, społecznych, ekonomicznych i kulturowych decydują o tym, że nie tylko w nauce o książce, ale także $w$ innych obszarach badawczych coraz trudniej pozostawać w granicach wyznaczonych przez ramy konkretnej dyscypliny. Efektywne uprawianie humanistyki wymaga zatem intensywniejszych poszukiwań w zakresie nowych propozycji pojęciowych, deskrypcyjnych, interpretatywnych czy metodologicznych. Interesująca i uniwersalną optykę w refleksji nad kulturą i światem wytworów człowieka oferują zwroty badawcze, które obecnie są istotną kategorią organizującą badania humanistyczne.

\section{ZWROTY BADAWCZE I ICH ZNACZENIE W NAUCE}

Obserwacji, analizie i charakterystyce przekształceń zachodzących w otaczającej nas rzeczywistości towarzyszą próby zdefiniowania ich 
natury. Jednoznaczna diagnoza współczesnych procesów jest problematyczna przede wszystkim ze względu na szybkie tempo pojawiania się zmian, a także ich zasięg, obejmujący rozległe i zróżnicowane obszary ludzkiej aktywności. Wśród terminów, które chętnie są wykorzystywane jako znaczniki dokonujących się przeobrażeń, często występuje słowo „rewolucja”. Denotuje ono zróżnicowane zjawiska wiązane z głębokim, kompletnym, nagłym i gwałtownym charakterem zmian. Termin „rewolucja" jest również postrzegany jako kategoria organizująca funkcjonowanie nauki, co w swojej książce Struktura rewolucji naukowych opisał Thomas Kuhn (Kuhn, 2001). Publikacja Kuhna pochodzi z lat 60. XX wieku, jednak od lat 90. terminem coraz chętniej stosowanym dla oznaczania przemian zachodzących w poszczególnych dyscyplinach naukowych stał się „zwrot". Jego usytuowanie w bliskości rewolucji naukowej ma swoje uzasadnienie, ponieważ często podkreślany jest związek pomiędzy transformacyjnym modelem nauki zaproponowanym przez Kuhna a wywrotową naturą zwrotów, szczególnie w niektórych obszarach badawczych.

Terminu „zwrot”, podobnie jak „rewolucja”, nie sposób ograniczyć jedynie do nauki. W szerokim ujęciu o naturze zwrotów wypowiedział się w publikacji Świat informacji Marek Hetmański (Hetmański, 2015), który dostrzegł ich użyteczność zarówno w różnych dyscyplinach naukowych, w rozważaniach nad cywilizacją jak i w publicystyce. Według Hetmańskiego termin „zwrot” stosowany jest wobec zasadniczych, radykalnych, nieodwracalnych i długotrwałych zmian, jakie zachodzą w obszarze nauki, ale także w sferze praktyki, obejmującej zachowania, zwyczaje czy technologie. Wywołuje je określony czynnik, którego dynamiczna, radykalna i nieodwracalna moc sprawia, że pojawiają się daleko idące przeobrażenia we wszystkich sferach życia zbiorowości i jednostek (Hetmański, 2015, s. 153). Może to być odkrycie naukowe, przełomowa teoria, nowa technologia, ale także idea społeczna lub koncepcja filozoficzna. Hetmański znaczenie tego pojęcia wyjaśnił w kontekście "zwrotu informacyjnego", wskazując przy tym siłę wpływu technologii kodowania, przetwarzania, magazynowania oraz komunikowania sygnałów i danych w systemach komputerowych na możliwości poznawcze człowieka. W podobny sposób o znaczeniu technologii teleinformatycznych wypowiadają się badacze, którzy używają określenia „rewolucja cyfrowa” dla oznaczenia procesów informatyzacji poszczególnych obszarów komunikacji społecznej. Chociaż obydwie nazwy opisuja pewien rodzaj zmian o radykalnym charakterze, analiza ich zastosowań pozwala na wskazanie różnicujących je kontekstów. Niekiedy bowiem termin „zwrot” stosowany jest wobec przemian, które nie mają wywrotowego charakteru i nie kończą się usankcjonowaniem nowego porządku. Tego typu sytuacja ma miejsce w odniesieniu do zwrotów badawczych występujących w humanistyce. W tym obszarze częstotliwość ich pojawiania się zdecydowanie wzrosła począw- 
szy od lat 90. XX w., co znalazło swój wyraz w określeniu „humanistyka zwrotów". Za pierwszy znaczący zwrot badawczy uznaje się zwrot lingwistyczny, za sprawą którego język stał się podstawowym układem odniesienia dla badań nad człowiekiem i kulturą. Obecnie lista zwrotów zawiera całkiem pokaźną ich liczbę. Wśród dotychczasowych propozycji wymienia się m.in.: zwrot afektywny, zwrot antropologiczny, zwrot dramaturgiczny, zwrot etyczny, zwrot ikoniczny, zwrot interpretacyjny, zwrot ku rzeczom, zwrot kulturowy, zwrot narratywistyczny, zwrot performatywny, zwrot poznawczy, zwrot pragmatyczny, zwrot retoryczny, zwrot topograficzny (Bohuszewicz, 2010). Do tego zestawu niektórzy zaliczają również zwrot cyfrowy, który wiązany jest z coraz większym zainteresowaniem humanistów procesem informatyzacji, jakiego doświadczają różne obszary kultury i nauki (Zwrot..., 2013).

Liczny i zróżnicowany zbiór dotychczasowych propozycji przeorientowania badań w obrębie humanistyki powoduje problemy ze wskazaniem zwrotu w jednym, określonym kierunku. Co prawda niektóre orientacje badawcze mają większą siłę oddziaływania niż inne (jak np. zwrot antropologiczny), dzięki czemu zmiana ma charakter niemal fundamentalny, jednak wielu z nich nie sposób posądzać o możliwość zastąpienia istniejących paradygmatów. W wyznaczonym przez nie polu nie pojawiają się również jakieś nowe, nieznane wcześniej pojęcia czy zjawiska. Ponadto nie dochodzi do trwałego zerwania z tradycyjnym sposobem uprawiania danej dyscypliny. Niemal wbrew etymologii samego terminu często okazuje się, że konkretny „zwrot” jest zaledwie postulatem, który ma służyć wyeksponowaniu określonej perspektywy badawczej. Akceptując złożoną naturę zwrotów i ich problematyczny charakter można dostrzec jednak kilka pozytywnych aspektów, jakie wiążą się z wykorzystywaniem formuły "zwrotu” w badaniach humanistycznych. Okazuje się bowiem, że dyscypliny zyskują nowe oblicze, dzięki usankcjonowaniu problemów, które wcześniej pozostawały poza ich głównym obszarem zainteresowań jako zbyt trywialne lub marginalne. Zwroty z jednej strony pozwalają zachować swoistość poszczególnych dyscyplin, ale podkreślają również ich punkty wspólne, pokrewieństwo różnych interpretacji zjawisk występujących w rozległym obszarze nauk o człowieku.

\section{ZWROT AFEKTYWNY A KULTURA KSIĄŻKI}

Niewątpliwie jednym z częściej i chętniej wykorzystywanych na gruncie humanistyki współczesnej zwrotów jest zwrot afektywny. Przyczyn jego popularności można upatrywać w nieadekwatności dotychczasowych narzędzi naukowych w wyjaśnianiu złożoności i nieprzewidywalności procesów zachodzących współcześnie w różnych sferach aktywności człowieka, a także w coraz bardziej dostrzegalnym wpływie emocji 
na kształtowanie się określonych zjawisk o charakterze komunikacyjnym, kulturowym czy społecznym.

Mianem zwrotu afektywnego w humanistyce określa się zatem orientację badawczą funkcjonującą na gruncie naukowym od połowy lat 90. Jej przedstawiciele dostrzegają rangę odczuć towarzyszących obcowaniu z poszczególnymi wytworami kultury. Uczestnictwo $\mathrm{w}$ procesach medialnych nie daje się bowiem sprowadzić jedynie do rozpoznania i zrozumienia sensu komunikatów obecnych w konkretnych dziełach literackich, artystycznych i innych. Afekty stają się w tym kontekście równoprawnym kryterium charakterystyki postaw i zachowań komunikacyjnych. Co więcej, traktowane są jako czynnik podważający przekonanie o uprzywilejowanej pozycji procesów poznania rozumowego w wytwarzaniu wiedzy. Zwiększone zainteresowanie uczuciowością człowieka dostrzec można nie tylko w humanistyce, ale także $w$ innych obszarach badawczych. Oprócz nauk tradycyjnie wiązanych z emocjami, jak filozofia, psychologia, socjologia itp., uaktywniają się dyscypliny, które niekoniecznie są łączone $\mathrm{z}$ analizowaniem wielowymiarowości ludzkiej egzystencji. Chodzi w tym przypadku o informatykę, a konkretnie jej dział funkcjonujący pod nazwą informatyka afektywna, obejmujący badania w zakresie relacji człowiek-komputer i sztucznej inteligencji.

Afekty, emocje i uczucia nie są wytworem współczesności, jednak niemal od zawsze, szczególnie w świecie naukowym, trwała mniej lub bardziej intensywna praca nad ich marginalizacją lub wręcz wyeliminowaniem z kręgu ludzkiego doświadczenia, prowadzona w imię doskonalenia sprawności umysłowej człowieka. Już starożytni filozofowie nie tylko przeciwstawiali sobie ducha i ciało, rozum i emocje, ale wręcz udowadniali, że droga do mądrości i cnoty prowadzi przez ujarzmienie afektów, które wprowadzają w życie pierwiastek nieracjonalności i chaosu (Burzyńska, 2015, s. 115-116). Tymczasem współcześnie za sprawą rewolucji cyfrowej została wykreowana nowa rzeczywistość komunikacyjna, która zdecydowanie sprzyja intensyfikacji emocjonalnych zachowań i wypowiedzi w dyskursie publicznym. Otwarty charakter mediów cyfrowych zapewnił nie tylko lawinowy wzrost liczby powszechnie dostępnych komunikatów, ale także zmienił ich charakter. Powstają pod wpływem chwili, impulsu i - co najważniejsze w tym kontekście - odzwierciedlają bieżące stany emocjonalne autorów. W dobie eksplozji informacji uwzględnienie w komunikacie pierwiastka afektywnego często decyduje o zwiększeniu jego szans na zyskanie masowego audytorium. Producenci medialni wykorzystują te tendencje i uczuciowość stała się dla wielu z nich najważniejszą wartością którą biorą pod uwagę tworząc ofertę dla klientów czy opracowując kampanie reklamowe swoich produktów i usług.

Wyodrębnienie sfery duchowej, odwołującej się do określonych stanów umysłowych i cielesnych człowieka, wymaga stosownej terminologii. Dla 
humanistycznego namysłu istotne jest rozróżnienie pomiędzy takimi pojęciami jak: afekt, emocja i uczucie, które należą do różnych kategorii. Każde $z$ nich pełni określoną rolę i zajmuje swoje miejsce $w$ teorii afektywnej. Afekty charakteryzowane są najczęściej przez pryzmat ich interpretacji dokonanej przez Briana Massumiego (Massumi, 2013). Stanowią swoistą intensywność doznania, emocjonalny stan zawieszenia wypełniony potencją zdarzeń, który jednak pozostaje umocowany somatycznie (Horodecka, 2015, s. 416). Afekty nie są łatwe do jednoznacznego zdefiniowania i identyfikowania, ponieważ traktowane są jako przedświadoma siła, która jest obecna zanim jeszcze pojawią się emocje i uczucia. Właściwością afektów jest zatem nieokreśloność, ale także nieuformowana potencjalność, która „umożliwia samo przeżywanie, wychwytywanie konkretnych wrażeń oraz przetwarzanie ich za pomocą świadomości i woli człowieka" (Koprowska, 2015, s. 103-104). Ich siła i znaczenie tkwią w tym, że mogą pobudzać do aktywności zarówno cielesnej, jak i intelektualnej, ale nie musi się tak zdarzyć. Kolejną cechą charakterystyczną jest zatem ich nieprzewidywalność. Obecność afektu stanowi jednak impuls do „głębokiego przeżycia i myśli ze względu na sposób, w jaki jest w stanie nas pochwycić, zmusić do zaangażowania" (Bojarska, 2013, s. 14). Chociaż afekty utożsamiane są z „nieświadomym doświadczeniem”, określają samą możliwość naszego przeżywania i przetwarzania docierających do nas bodźców. Afekty zidentyfikowane, skonkretyzowane, często nazwane i przede wszystkim wpasowane w istniejący porządek społeczno-językowy określonej grupy mogą przekształcać się w emocje. Emocja jest zatem stanem związanym ze społecznym funkcjonowaniem jednostki. Stanowi subiektywny akt przypisania jakości danemu doświadczeniu, który jest zgodny z odpowiednim dla konkretnej wspólnoty wzorcem kulturowym (Bojarska, 2013). Emocje są wyrażane i pozostają najłatwiejsze do zidentyfikowania $\mathrm{w}$ tej triadzie. Uczucia z kolei mają charakter jednostkowy, prywatny i biograficzny. Pojawiają się w kontekście indywidualnych przeżyć i osobistych wrażeń osoby, która dysponuje własnym bagażem doświadczeń. Przy czym afekty uznaje się za bliższe właśnie uczuciom niż emocjom, przede wszystkim z tego względu, że mniej odwołują się do kategorii społecznych czy kulturowych.

Przeorientowanie badań bibliologicznych w duchu „zwrotu afektywnego" wymaga zatem założenia, że oddziaływanie książki na odbiorcę stanowi złożony mechanizm, który oparty jest nie tylko na tekście i sposobach jego istnienia w książce, ale także na obecności innych czynników w znacznej mierze odwołujących się do ludzkiej uczuciowości. Przyjęcie perspektywy afektywnej nie oznacza, że można pominąć dotychczasowe dokonania bibliologii w tym zakresie, które wiążą się z zagadnieniami miłości i nienawiści do książek. Bibliofilstwo oznaczało jednak najczęściej połączenie miłości ze znawstwem i zbieractwem książek. Strach odnoszą- 
cy się do książki, jeśli funkcjonował pod nazwą bibliofobii, raczej wiązany był z lękiem przed siłą oddziaływania słowa pisanego w kontekście kulturowym i społecznym. W połączeniu z nienawiścią mógł prowadzić do biblioklazmu, czyli fizycznego eliminowania książek z pobudek religijnych, ideologicznych, politycznych i/lub obyczajowych. W sposób szczególny na gruncie naukowym wykorzystywano również wiedzę dotyczącą wpływu książek na emocjonalność człowieka w zakresie biblioterapii. Jej podstawą jest bowiem stosowanie w pracy terapeutycznej odpowiednich materiałów piśmienniczych, które inicjują pozytywne zmiany w postawach, zachowaniach i emocjach człowieka dotkniętego problemami zdrowotnymi (Woźniczka-Paruzel, 2010, s. 116-117). Istotne dla badań nad czytelnikiem były również opracowania wskazujące na emocjonalny potencjał literatury ujawniający się w procesach lekturowych (Wojciechowski, 1999). Szczególne znaczenie przypisywano czynnikowi emotywnemu w czytelnictwie dzieci i młodzieży (Papuzińska, 1996).

Wcześniejsze dostrzeganie tych zjawisk na gruncie bibliologii nie zamyka jednak drogi do ich reinterpretacji czy pogłębienia badań w tym obszarze. Warto przy tym wykorzystać dotychczasowe dokonania badaczy identyfikujących się z humanistycznym rozumieniem zwrotu afektywnego. Konkretne analizy uwzględniające identyfikację i kategoryzację afektów, emocji i uczuć książkowych powinny zatem umożliwić zróżnicowanie kulturowego postrzegania znaczenia książki i roli osobistych odczuć związanych z jej użytkowaniem. Interesującym problemem pozostaje również weryfikacja emocji leżących u podstaw traktowania książki jako sacrum, obiektu nabożnej czci, ale również przedmiotu, który wzbudza irytację i niechęć. Może się wydawać, że najtrudniejszym zadaniem pozostanie łowienie afektów książkowych, trudno jednak na tej podstawie zaprzeczyć ich istnieniu. Ujawniają się przecież w myśleniu o książkach, ale także w działaniu, które wymyka się racjonalnej interpretacji, jak chociażby sytuacje, gdy nabywamy czy wybieramy do lektury książkę pod wpływem impulsu. Afektywne podejście do książki powinno również uwzględniać analizę uniwersum piśmiennictwa pod kątem potencjału emotywnego poszczególnych typów dokumentów czy weryfikację tych elementów książki, które mają wpływ na ujawnianie się określonych emocji i uczuć. W tym zakresie szczególnie obiecującym polem pozostaje graficzne i typograficzne wyposażenie tradycyjnej książki. Możliwych do wyznaczenia obszarów badawczych można wymienić więcej, jednak jednym z istotniejszych wydaje się charakterystyka emocji książkowych, których doświadczają współcześni czytelnicy. Wobec konkurencji ze strony przemysłu medialnego i bogatej oferty treściowej dystrybuowanej przez różne kanały komunikacyjne czytanie książek w dalszym ciagu pozostaje istotną sferą aktywności konkretnych grup odbiorców. Warto zatem wykorzystać kontekst afektywny do bliższego przyjrzenia się ich doświadczeniom i motywacjom. 
Obiecującą perspektywę w zakresie doboru materiału badawczego stwarzają liczne zbiory sieciowe, które obfitują w wypowiedzi internautów na różne tematy, w tym odnoszące się do szeroko rozumianej kultury książki. Zweryfikowaniu ich przydatności posłużyło badanie zrealizowane w oparciu o zasoby forum Książki na witrynie Gazeta.pl (http:// forum.gazeta.pl/forum/f,151,Ksiazki.html). Podstawowym celem przeprowadzonej analizy było rozpoznanie zawartości forum pod kątem emocji ujawnianych przez czytelników w dyskusjach o książkach. Rozmiar źródła (Forum Książki w październiku 2017 r. liczyło 282558 wpisów) wpłynął na rezygnację z ujęcia ilościowego na rzecz jakościowej analizy zawartości, w oparciu o wyselekcjonowany zbiór wpisów. Korpus materiałowy został wyodrębniony za pomocą dostępnej na stronie forum wyszukiwarki. Ten sposób postępowania wymagał zapytania wyszukiwawczego w postaci nazwy emocji. Ze względu na wstępny charakter badań naturalnym wyborem stał się zestaw emocji określanych jako pierwotne, podstawowe czy uniwersalne. Kryteria wyszukiwania uwzględniały zatem strach, złość, smutek i radość (bez ich bliskoznacznych odpowiedników). Gromadzenie danych realizowane było od 12 do 25 listopada 2017 r. Mechanizm wyszukiwarki wykazał 3984 wyniki (radość - 1845, strach 1021, smutek - 865, złość - 253), jednak ich pozyskiwanie zostało ograniczone do pierwszych 20 stron wyświetleń. Dalszy przebieg postępowania uwzględniał lekturę uzyskanych za pomocą wyszukiwarki wpisów, dzięki czemu wyeliminowane zostały posty, w których poszczególnych emocji doświadczali bohaterowie powieści lub pojawiały się one w tytułach książek, cytowanych fragmentach czy mottach. Z korpusu usunięte zostały również wpisy, w których emocje występowały w powiedzeniach (np. „rachu, ciachu i po strachu”). W efekcie uzyskano zbiór 299 wpisów (radość - 94, smutek - 92, złość - 62, strach - 51) wytypowanych do analizy. Weryfikacja zawartości uzyskanego korpusu potwierdziła, że internauci $\mathrm{w}$ swoich wypowiedziach dotyczących książek posługują się słowami, których desygnaty mieszczą się w kategorii emocji uniwersalnych. Stworzyła również możliwość wytypowania zbioru problemów uwzględniających charakterystyczne wystąpienia komponentu emotywnego we współczesnej kulturze książki. Wśród nich najistotniejszą rolę odgrywają emocje jako integralny element czytania, ale także czynnik decydujący o podjęciu lektury lub jej zaniechaniu czy porzuceniu. Znaczące pozostają również związki pomiędzy emocjami a określonymi tytułami, gatunkami literackimi itd. Kolejnym zagadnieniem jest „emocjonalna pamięć lekturowa" charakterystyczna dla indywidualnych czytelników, która pełni istotną rolę w kontekście relacji rodzic-dziecko. Użyteczność emocji to następny obszar, w ramach którego książka może być traktowa- 
na jako narzędzie inicjujące określone odczucia, ale niekiedy pozwala się również od nich uwolnić. W analizowanym materiale pojawiły się ponadto wypowiedzi wskazujące na pozytywną lub negatywną ocenę emocji wywołanych przez lekturę. Zgromadzony materiał wskazuje również na możliwość powiązania odpowiednich emocji z innymi niż czytanie działaniami (nabywaniem książek, ich pożyczaniem lub obdarowywaniem nimi). Wypowiedzi nacechowane emocjonalnie dotyczyły ponadto autorów, wydawców oraz ogólnej sytuacji na rynku książki. Szczegółowa interpretacja wpisów użytkowników forum zgromadzonych w korpusie materiałowym znajduje się poniżej.

Emocje pozostają zatem niezwykle istotnym elementem procesów lekturowych. Deklaracje czytelników, poparte najczęściej określonymi doświadczeniami, są jednoznaczne - książki powinny dostarczać emocji i często doskonale wywiązują się z tego zadania. Emocje towarzyszące lekturze są niekiedy ważniejsze od samej opowieści i trwalej zapadają w pamięć niż treść książki. Przywołanie po latach tytułu, z którym związane były określone namiętności, często sprawia ogromną radość. Ponownej lekturze może jednak towarzyszyć obawa, czy podczas czytania pojawią się te same odczucia. Emocjonalny odbiór lektury rozpoczyna się już w wieku dziecięcym. Emocje pełnią również ważną funkcję w przekazywaniu umiejętności czytelniczych kolejnym pokoleniom. Dokonywane wówczas wybory lekturowe pozwalają skonfrontować własne odczucia z przeszłości z tymi, których doświadczają współcześni młodzi odbiorcy literatury. Rodzic czytający swojemu dziecku ma również okazję przekonać się, czy dawne emocje powróciły po latach. Radość dziecka towarzysząca lekturze staje się równocześnie radością rodzica, który dostarczył lub przeczytał dobrą książkę.

Zestaw oczekiwanych doznań może mieć charakter kompletny i heterogeniczny (np. od udręki, poprzez zachwyt i radość, po smutek i zniechęcenie). Określone gatunki literackie są jednak niekiedy utożsamiane z konkretnymi emocjami. Lekturze horrorów (a także thrillerów) powinien towarzyszyć strach. Gdy czytelnik doświadcza tej emocji, może mieć ona somatyczny charakter w postaci kołatania serca, pocenia się rąk, a także problemów z zasypianiem. Strachowi może towarzyszyć tajemniczość, niekiedy obrzydzenie, ale cenione jest również jego połączenie z humorem. Czytelnicy chcą się bać, a książka zapewnia bezpieczny sposób przeżywania strachu, ponieważ w każdej chwili można ją zamknąć i przerwać lekturę. Strach dla człowieka pierwotnego był ważnym czynnikiem zapewniającym przetrwanie, ponieważ pozwalał uniknąć niebezpieczeństw. W tym kontekście zastanawiać może, co kryje się za współczesnym przeżywaniem „nieprawdziwego strachu” wywoływanego przez lekturę. Okazuje się, że niekiedy chodzi o eskapistyczne podejście do rzeczywistości, polegające na odrywaniu się od własnych kłopotów na rzecz perypetii 
bohatera. W przypadku niektórych czytelników jest to również pewnego rodzaju kompensacja - decydują się na lekturę horrorów, chociaż uważają się za ludzi bojaźliwych w życiu codziennym. Odpowiednia książka może być również wykorzystywana jako narzędzie w zmaganiach ze strachem. Zalecane jest bowiem podejmowanie lektury wtedy, gdy ogarnia strach (np. przed sesją) lub w sytuacjach wymagających oswojenia się z jego naturą. Straszna lektura nie musi łączyć się z czytaniem horrorów czy thrillerów. Przerażenie mogą wywoływać książki dla dzieci, teksty religijne, publikacje popularnonaukowe czy literatura faktu. W tym ostatnim przypadku okazuje się, że dawna czy współczesna rzeczywistość może przerażać bardziej niż świat powstały wyłącznie w umyśle pisarza.

Literatura faktu wzbudza nie tylko strach, ale niekiedy wręcz złość na opisany w niej świat. Obiektami złości często okazują się również bohaterowie występujący w tekstach literackich. Złość na książkę może mieć różne oblicza - niechęć do przedstawionej w niej opowieści, ale także do autora, który zadecydował o tragicznym losie bohaterów. Wzmocniona poczuciem rozczarowania może skutkować gwałtownymi reakcjami czytelników. Książki, które stały się przyczyną udręki czytelniczej (a mogą nimi być teksty literackie, lektury szkolne, podręczniki akademickie itd.) są rzucane o ścianę, a niekiedy wręcz niszczone (np. przez spalenie). Złość, jaką wywołują książki, można wykorzystać w roli panaceum na doskwierające $w$ danym momencie uczucia (chociaż jest to dosyć przewrotna terapia), ponieważ jej natężenie jest w stanie przykryć smutek, troski a nawet rozpacz.

Terapeutyczne walory książki najczęściej odnajdywane są i wykorzystywane w chwilach smutku. W czasie choroby i żałoby, a także wtedy, gdy pogoda czy otaczająca rzeczywistość skutkuje melancholia, odpowiednia książka okazuje się doskonałym remedium, które poprawia nastrój, oferuje wytchnienie. Nie wszyscy czytelnicy sięgają jednak po nią aby poczuć radość istnienia. Część z nich woli lektury, dzięki którym mogą pogrążyć się w smutku, co ma walor oczyszczający i sprawia, że łatwiej im uporać się z własnym przygnębieniem. Niekiedy smutek w tekście literackim jest tak absorbujący, że można zapomnieć o własnym. „Przerabianie” smutku za pomocą książki nie zawsze wiąże się ze świadomym wyborem czytelniczym. Zdarza się, że gorycz towarzysząca lekturze zaskakuje czytelnika i wówczas książki mogą być klasyfikowane jako „wykańczające psychicznie", przytłaczające (czemu może towarzyszyć uczucie beznadziei) lub oczarowujące (nostalgia, piękno sprawiające przyjemność). Smutek towarzyszący lekturze nie jest zatem oceniany jednoznacznie. Może być traktowany jako niepożądany efekt określonych wyborów lekturowych, ale są też czytelnicy, którzy cenią sobie tego typu emocje podczas czytania. Co więcej, wręcz poszukują książek, które wywołują głęboki, przeszywający i bezbrzeżny smutek. 
Wielu czytelników deklaruje jednak, że książka ma przede wszystkim sprawiać radość. W wywołaniu tej emocji upatrują sens i cel czytania. Zadowolenie płynące z lektury może mieć wymiar totalny i często charakteryzowane jest jako „wielka radość" czy „niewyobrażalna radość". Szczególną radość sprawia odkrywanie kolejnych elementów fabuły czy odnajdywanie własnych cech w charakterystykach bohaterów. Dla niektórych czytelników jej czerpanie jest ważniejsze niż inne motywacje, takie jak chęć zdobycia wiedzy czy potrzeba poznania kanonicznych tytułów. Czytanie ma być przyjemnością, więc lekturę książki niespełniającej tego warunku można przerwać w dowolnym momencie i porzucić ją bez żalu.

Ogólna radość czytania zakłócana jest niekiedy przez specyficzny rodzaj strachu. Wiąże się on z ogromną liczbą książek, która może stać się czynnikiem paraliżującym zapędy czytelnicze. Przytłaczający bowiem pozostaje fakt, że nie sposób przeczytać ich wszystkich. Szczeremu przyznaniu się do nieznajomości książek może towarzyszyć smutek. Niewielką ulgę przynosi ograniczenie całego ich uniwersum do określonego kanonu, typu literatury czy nowości wydawniczych, ponieważ wyselekcjonowany zbiór w dalszym ciągu może mieć spore rozmiary a zawarte w nim tytuły prowadzą do kolejnych potencjalnych wyborów lekturowych. Strach przed liczebnością książek na niektórych czytelników działa mobilizująco, dzięki czemu starają się postępować bardziej efektywnie (przygotowują listy i stosy książek do przeczytania, aby nie tracić czasu na szukanie kolejnych tytułów). Na innych z kolei działa deprymująco, co może skończyć się ogólnym podważaniem sensu czytania. Strach przed książką w tym kontekście wiąże się zatem z przymusem czytelniczym, bez względu na to, czy czytelnicy sami go sobie narzucają (ponieważ np. chcą uchodzić za osoby oczytane), czy czynią to inni (lektury szkolne, modne książki itd.). W uwalnianiu się od tego strachu pomagają różne strategie. Jedna z nich polega na losowym wyborze książek do lektury. Kolejną metodą jest ściśle ograniczona i kontrolowana lista priorytetów czytelniczych, czytanie według klucza (określona problematyka, twórczość konkretnego autora, epoka literacka, gatunek literatury itd.). Pomocne okazuje się również "czytanie mechaniczne", polegające na automatycznym eliminowaniu kolejnych nieprzeczytanych książek bez specjalnej troski o wielkość całego ich zbioru. Jednak najpopularniejszym sposobem radzenia sobie z przytłaczającym bezmiarem tekstów niepoznanych jest świadomość, że obcowaniu z książkami powinna towarzyszyć przede wszystkim radość czytania, a nie imperatyw pochłonięcia ich wszystkich. Ten strach przed książkami wiąże się zatem ściśle z motywacją - jeśli ktoś czyta z obowiąz$\mathrm{ku}$, to potencjalna skala lektur może przerażać, jeśli dla przyjemności, ich liczba nie ma większego znaczenia.

Strachów związanych z czytaniem jest zresztą o wiele więcej. Konieczność przeczytania nielubianej książki lub publikacji niecierpianego autora 
wzbudza strach. Objętość kilkusetstronicowego tomu może budzić poważny niepokój. Nawet kiedy czytelnik trafia na dobrą i ciekawą lekturę niekiedy pojawia się strach, że mogła zostać przeoczona. Obawiać się można zarówno książek złych, które mogą okazać się nietrafionymi inwestycjami pod względem finansowym i czasowym, jak i dobrych, niepozwalających oderwać się od czytanego tekstu. Emocjonalne zaangażowanie w lekturę książki jest dla czytelników stanem pożądanym i oczekiwanym. Pogrążanie się $\mathrm{w}$ fikcyjnych światach budzi jednak niekiedy strach, że być może książki nie są tego warte, a związane z lekturą oderwanie od rzeczywistości niebezpieczne, co może nawet skutkować krótszą lub dłuższą przerwą w czytaniu. Późniejszy powrót do literatury może z kolei zaowocować smutkiem, ile czasu zostało stracone na „nieczytanie”. W podobnym kontekście pojawia się również złość. Książki, które rozczarowują budzą ją ze względu na stratę czasu przeznaczonego na lekturę, ale także pieniędzy wydanych na nieudany zakup. Złość spowodowana naiwną wiarą w zapewnienia wydawcy lub innych czytelników o wysokiej jakości publikacji może być wówczas skierowana na samego siebie. Nawet w przypadku wartościowej książki pojawia się złość, gdy nie można kontynuować czytania, ponieważ np. towarzysząca jej podróż dobiegła końca. Naturalny koniec lektury (niewymuszony przez okoliczności) jest również niekiedy powodem smutku. Złościć może ponadto utrudnianie korzystania z książki, jakim dla niektórych czytelników są różne ingerencje w jej treść polegające na dopisywaniu informacji, robieniu notatek na marginesach czy podkreślaniu i zaznaczaniu fragmentów (chociaż trzeba przyznać, że niektórzy z nich cenią sobie tego typu zabiegi). Złość może zostać ponadto wywołana brakiem książek do czytania.

Emocji dostarcza nie tylko samo czytanie, ale także różne działania okołolekturowe. Jeśli książka wywołała radość, sięganie po kolejne tytuły z tej samej serii lub tego samego autora również często jej dostarcza. Pozytywne emocje ujawniają się wraz z informacjami o wznowieniach tytułów pożądanych i poszukiwanych przez czytelników. Szczególny rodzaj radości towarzyszy polowaniom na książki w księgarniach i w antykwariatach, zwłaszcza wtedy, gdy chodzi o uzupełnienie własnej biblioteczki o brakujące egzemplarze. Konieczność wprowadzania ograniczeń w zakupach książek (ze względów finansowych, lokalowych itd.) wywołuje smutek. Szczególnie u tych czytelników, których bardziej martwi niedobór książek niż ich brak. Jeśli problem z nadmiarem tomów wynika z braku miejsca na ich przechowywanie, można go rozwiązać za pomocą e-booków i czytników. Komfort gromadzenia dowolnej liczby publikacji w pamięci urządzeń cyfrowych przynosi sporo radości. Nabywanie nowych tytułów może również wiązać się z kupowaniem prezentów książkowych. W tym przypadku radość i satysfakcja często są odłożone w czasie do momentu, kiedy okaże się, czy prezent utrafił w gusta obdarowanego. Sam prezent 
książkowy jest charakteryzowany jednoznacznie - ma sprawić radość osobie, która go otrzyma. Spełnienie tego warunku wymaga niekiedy podejmowania różnych działań, polegających m.in. na konsultacjach z innymi czytelnikami w kwestii wyboru odpowiedniego tytułu. Radość sprawia również odnajdywanie na półkach innych czytelników książek odpowiadającym własnym gustom. Za sprawą lekturowych wyborów następuje wówczas identyfikacja drugiej osoby oraz określenie stopnia jej zgodności z określonym profilem zainteresowań. Relacje między czytelnikami mogą jednak budzić również złość. Zwłaszcza w sytuacji, gdy dochodzi do wymiany zdań i opinii o ulubionych tytułach. Podawane przykłady mogą wówczas wywoływać gniew połączony z ironią u czytelników, którzy charakteryzują się odmiennymi upodobaniami. Prawdziwa skala złości wśród posiadaczy książek ujawnia się jednak dopiero w sytuacji, gdy pożyczone tomy nie wracają do właściciela. Ze względu na ubytki w domowym księgozbiorze, niektórzy z nich $\mathrm{w}$ ogóle rezygnują z udostępniania własnych egzemplarzy, co z kolei budzi złość u tych, którzy chcieliby z nich skorzystać.

Powodem złości są również ci, którzy książki tworzą. Nazwiska poszczególnych autorów wywołują złość, czemu towarzyszy brak akceptacji dla ich twórczości, ale także niekiedy sprzeciw wobec podejmowanej przez nich działalności pozaliterackiej (ogromne kontrowersje wzbudziły np. wypowiedzi Siergieja Łukjanienki na temat niepodległości Ukrainy). Jednak w przypadku wielu pisarzy wiadomość o ich śmierci budzi ogromny smutek. Z kolei informacje o nagrodzie przyznanej ulubionemu autorowi (przede wszystkim literacka Nagroda Nobla i Nagroda Literacka "Nike”) skutkują eksplozją radości. Złościć może również mało profesjonalne tłumaczenie. Wydawnictwa wywołują złość, gdy proponują produkt, który budzi zastrzeżenia czytelników - może to być okładka niskiej jakości lub nieatrakcyjne formy promocji. Ogólnie złość powoduje niedopracowany i/lub niepełny (np. pozbawiony komentarza wydawcy) produkt książkowy. Smutkiem natomiast napawa trudna sytuacja i problemy na rynku książki.

Przeprowadzone badanie ujawniło zatem obecność konkretnych emocji w tych wypowiedziach internautów, które odnosiły się zarówno do samej książki, jak i wielu innych kwestii związanych z jej współczesnym funkcjonowaniem. Posty czytelników zawierają nie tylko deklaracje dotyczące doświadczanych emocji, ale często uwzględniają również przyczyny i skutki ich zaistnienia. Emocje wiązane są niekiedy z podejmowaniem określonych działań, których spektrum jest dosyć rozległe i wskazuje na konkretne strategie w zakresie czytania czy zapewniania dostępu do książki. Odczucia towarzyszące lekturze wykorzystywane są również do wartościowania i oceny zarówno poszczególnych tytułów, jak i różnych innych elementów kultury książki. Uwzględniony w badaniu zestaw emocji 
został ograniczony do strachu, złości, smutku i radości, jednak nawet na tym podstawowym poziomie zawartość sieci okazała się wartościowym materiałem. Pełen obraz afektów książkowych, opracowany z wykorzystaniem zasobów internetowych, wymaga z pewnością dalszych i bardziej szczegółowych badań.

\section{BIBLIOGRAFIA}

Bohuszewicz, Paweł (2010). Po czy w ramach poststrukturalizmu? „Zwroty” badawcze wobec przełomów paradygmatycznych w najnowszym literaturoznawstwie polskim. W: "Zwroty" badawcze w humanistyce. Konteksty poznawcze, kulturowe i społeczno-instytucjonalne. Red. J. Kowalewski, W. Piasek, Olsztyn: Instytut Filozofii Uniwersytetu Warmińsko-Mazurskiego, s. 15-43 [online]. Academia; [dostęp: 25.01.2018]. Dostępny w WWW: $<$ https://www.academia.edu/8170720/Po_czy_w_ramach_poststrukturalizmu_Zwroty_badawcze_wobec_przełomów_w_najnowszym_literaturoznawstwie_polskim>.

Bojarska, Katarzyna, (2013). Poczuć myślenie: afektywne procedury historii i krytyki (dziś). Teksty Drugie, nr 6, s. 8-16.

Burzyńska, Anna (2015). Afekt - podejrzany i pożądany. W: Kultura afektu - afekty w kulturze. Humanistyka po zwrocie afektywnym. Pod red. R. Nycza, A. Łebkowskiej i A. Daukszy. Warszawa: Instytut Badań Literackich PAN - Wydawnictwo, s. 115-134.

Hetmański, Marek (2015). Świat informacji. Warszawa: Difin.

Horodecka, Magdalena (2015). Afekty i emocje w reportażu literackim. Perspektywa genologiczna i antropologiczna. W: Kultura afektu - afekty w kulturze. Humanistyka po zwrocie afektywnym. Pod red. R. Nycza, A. Łebkowskiej i A. Daukszy. Warszawa: Instytut Badań Literackich PAN - Wydawnictwo, s. 415-441.

Koprowska, Karolina (2015). Historia mówiona a afektywny krajobraz pamięci. W: Kultura afektu - afekty w kulturze. Humanistyka po zwrocie afektywnym. Pod red. R. Nycza, A. Łebkowskiej i A. Daukszy. Warszawa: Instytut Badań Literackich PAN - Wydawnictwo, s. 99-112.

Kuhn, Thomas S. (2001). Struktura rewolucji naukowych. Warszawa: Fundacja Aletheia.

Massumi, Brian (2013). Autonomia afektu. Teksty Drugie, nr 6, s. 111-134.

Papuzińska, Joanna (1996). Dziecko w świecie emocji literackich. Warszawa: Wydaw. SBP.

Radomski, Andrzej; Bomba, Radosław, red. (2013). Zwrot cyfrowy w humanistyce: Internet, Nowe media, Kultura 2.0 [online]. Lublin: E-naukowiec; [dostęp: 2.05.2018]. Dostępny w WWW: <http://e-naukowiec.eu/wp-content/uploads/2013/05/Zwrot_cyfrowy_w_humanistyce.pdf $>$.

Wojciechowski, Jacek (1999). Czytelnictwo. Kraków: Wydaw. Uniwersytetu Jagiellońskiego. Woźniczka-Paruzel, Bronisława (2010). Pogranicza bibliologii - o metodologicznych problemach z biblioterapią. W: Książk zawsze obecna. Prace ofiarowane Profesorowi Krzysztofowi Migoniowi. Wrocław: Wydaw. Uniwersytetu Wrocławskiego, s. 111-121.

Tekst w wersji poprawionej wptyną do Redakcji 6 maja 2018 r. 
MAŁGORZATA GÓRALSKA

Institute of Information and Library Studies

Wroclaw University

e-mail: malgorzata.goralska@uwr.edu.pl

\section{THE AFFECTIVE TURN \\ AND THE CONTEMPORARY STUDIES ON BOOKS AND READERS. A PRELIMINARY RESEARCH}

KEYWORDS: Affective turn, Book studies. Readers. Book-related emotions.

ABSTRACT: Thesis/Objective - The affective turn is one of more dynamic research trends in contemporary humanities. The significance of emotive factors in communication processes can also be noticed when one considers behaviors and spoken/written messages providing the base for information exchange in mass media. The aim of this article is to present options for the development of research on affects, emotions and feelings specific for the book culture, including an attempt to prove the usefulness of web resources for this research. Research methods - The author conducted desk research based on the data covering posts added to Książki (Books) message board located at Gazeta.pl website. Taking into consideration the limitations of this research, she analyzed only posts including words describing basic emotions (fear, anger, sadness and joy). Results and conclusions The result of the research was a complex and multidimensional landscape of book-related emotions and the confirmation of the usefulness of web resources for further research in this area. 